\title{
Current Issues of Automobile Insurance ${ }^{\#}$
}

\author{
(Discussion about automobile insurance)
}

Eva DUCHÁČKOVÁ*

An increasing number of automobiles, greater traffic density, and improvements in car building have all resulted in higher speeds, an increased value of vehicles, and in a rising amount of negative consequences in form of material damage to vehicles and other assets, health, and accident victims. In this environment, automobile insurance plays an integral part. Motor third party liability insurance is considered the basic insurance coverage. This insurance product is important due to the liability factor and due to the state regulation, i.e. the EU regulation in our case. Among the most significant insurance products is, however, motor hull insurance. The share of premium written in automobile insurance on the insurance markets and the forms of current insurance products are changing. At the same time, changes in the already existing products are in progress, and new insurance products are introduced as a result of the changing demand. Therefore, the past two years have prompted insurers to react to an intensifying competition in the auto insurance markets. Aim of the article is analysis of changes in the market car insurance in the current period.

\section{European Auto Insurance Market}

Auto insurance is one of Europe's most significant industries, which results from the amount of actively used automobiles and construction of the auto insurance policy. (Majtánová et al. 2006, p. 155)

The number of automobiles is increasing on the European continent and according to Swiss Re currently reaches the figure of around 300

\footnotetext{
\# The article is processed as an output of a research project Changes in the role and position of the insurance sector in the global era in the world and Czech Republic registered by the Czech Science Foundation under the registration number 402/09/1507. Prof. Ing. Eva Ducháčková, CSc. - Professor; Department of Banking and Insurance, Faculty of Finance and Accounting, University of Economics, Prague, W. Churchill Sq. 4, 13067 Prague 3, Czech Republic; <duchack@vse.cz@vse.cz>.
} 
million vehicles. Individual countries differ to a certain degree in the vehicle per capita ratio. For example, this index is 0.7 in Germany, 0.9 in Italy, 0.4 in Poland and in Hungary, and 0.5 in the Czech Republic. There is, however, a large number of risks involved in the automotive industry with the most significant one being collisions, which can lead to loss of life, damage to health, material damage (to the automobile, transported items, and other assets incurred in traffic accidents), losses of benefits , and third-party compensation. Other risks include theft, vandalism, natural disasters, machinery breakdown risks, and risks related to a breach of contract during transportation, etc.

Fig. 1: Premium written in Auto Insurance Premium: Motor third party liability insurance and Motor hull Insurance (in mil. EUR)

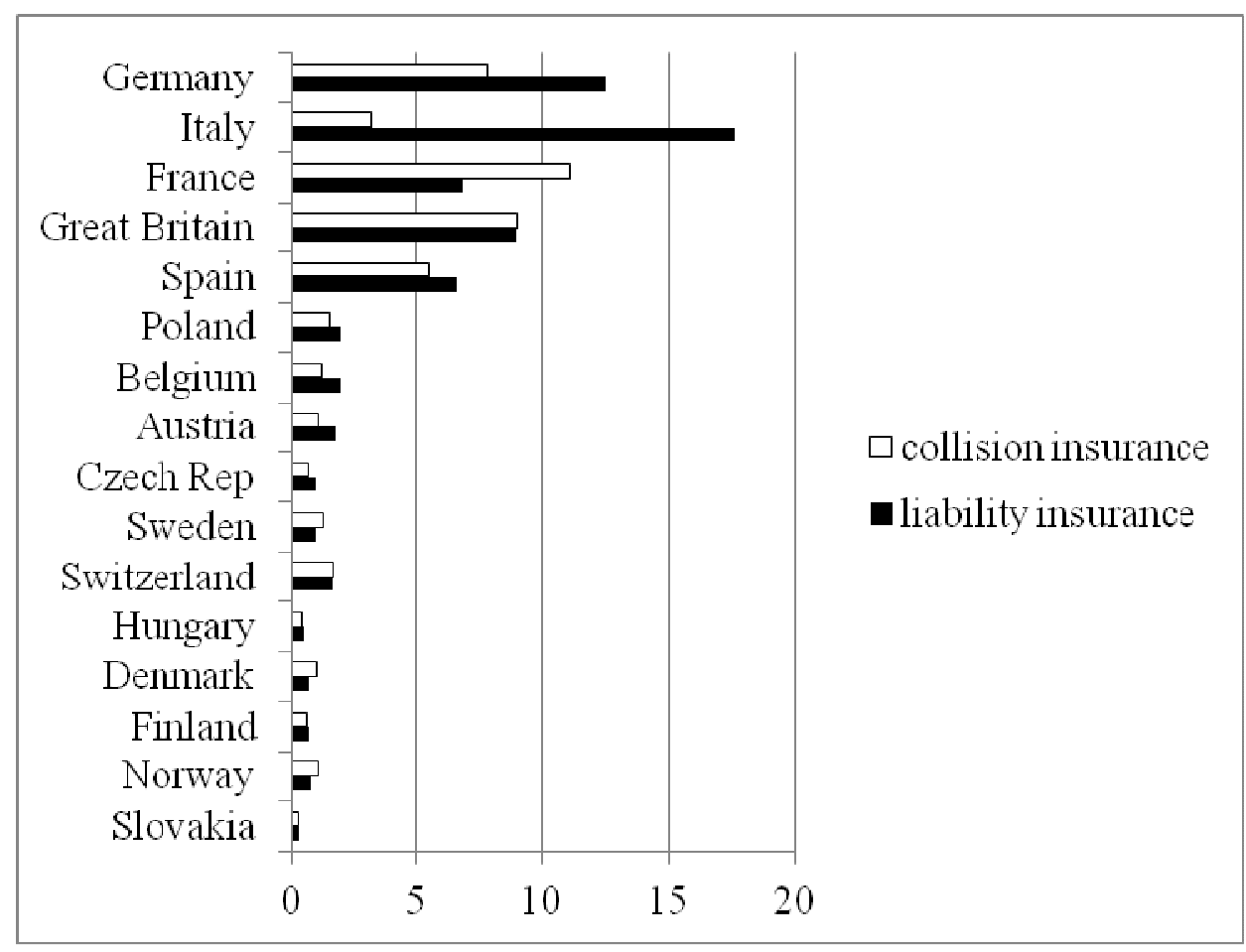

Source: Bauer - Melle (2007), p. 10.

This insurance segment represents a significant market share in the insurance markets. Equally, in the developed countries, the share of mandatory non-life insurance premium for liability insurance fluctuates in 
the tens of percentage points, for instance, about $45 \%$ in Italy, $17 \%$ in Germany and Great Britain, and $21 \%$ in Spain.

Collision insurance aimed at covering property damage to vehicles (due to collision, theft, natural disaster, mechanical breakdown, roadside assistance, vandalism) varies from country to country.

Basic insurance products in the automobile insurance industry are liability and collision insurance. Liability insurance, whose format is strictly regulated in the $\mathrm{EU}$, is mandatory due to its coverage of the aggrieved individual/s. In addition to its mandatory character, the regulation also specifies the payment of the insured claim (i.e. to the aggrieved individual involved in the traffic accident even when damage incurred cannot be claimed on the basis of the insurance contract), insurance provider rules, the set-up of an institution specializing in this type of insurance (i.e. the Czech Insurers' Bureau in the Czech Republic), whose members are insurers providing liability insurance. Moreover, it also regulates the minimal amount of insurance benefit limits which have been and most likely will be raised in due course based on the needs of the scope of coverage. Currently, this figure stands at $1 \mathrm{mil}$. EUR, but it is expected to rise to around 5 to 10 mil. EUR (Vostatek, 1996, p. 411).

\section{Czech Auto Insurance Market}

Auto insurance, in particular liability insurance (which represents about $26 \%$ of the mandated coverage in the non-life insurance sector) takes up a large portion of the insurance market. Similar to the situation in the developed countries, the development in the Czech Republic points to a declining auto insurance market share (see Fig. 2) despite a long-term increase in the number of cars. This reduction in the market share has not only been affected by the development in other sectors of the insurance market (i.e. life insurance, liability insurance, credit insurance, and surety underwriting), but, in fact, the last short period as shown by Fig. 2 has experienced a dramatic drop.

The apparent decline is triggered by a very strong competition in the Czech automobile insurance market. In this respect, an important factor is a drop in the coverage price. For example, the average price of a new insurance contract for liability coverage was $4354 \mathrm{CZK}$ at the beginning of 2006 as compared to 2665 CZK at the beginning of 2011 (Šitner, 2011). Lower automobile insurance prices, particularly in liability 
coverage, are, however, running into an issue of insufficient coverage of incurred damage. Therefore, prices will have to be adjusted according to more objective standards in the future.

At the same time, insurance payments have been on the increase. The amount of claims filed in 2010 in terms of mandatory insurance reached the amount of 284000 (Czech Insurers' Bureau, 2000-2010). A higher amount of claims is generally filed only for property damage where the average claim amounts to about $26000 \mathrm{CZK}$. There is a lower amount of claims filed in relation to damage to health, but the damage is about ten times higher (Czech Insurers' Bureau, 2000-2010). Compared to 2008, the volume of mandatory collision insurance dropped by about $1 \%$ in 2009. As compared to 2009, 2010 recorded a decline in mandatory collision insurance by about $5 \%$ and in liability insurance by about $6.5 \%$. This drop is significant primarily in case of Česká pojišt'ovna, a major insurer on the Czech market. In 2009, their mandatory collision insurance dropped by $7.2 \%$ and liability insurance by $8.2 \%$. Furthermore, when compared to 2009 , their mandatory collision insurance declined by $11.3 \%$ and liability insurance by $11.6 \%$.

Fig. 2: Auto Insurance Share in the Premium written on the Czech Insurance market (in \%)

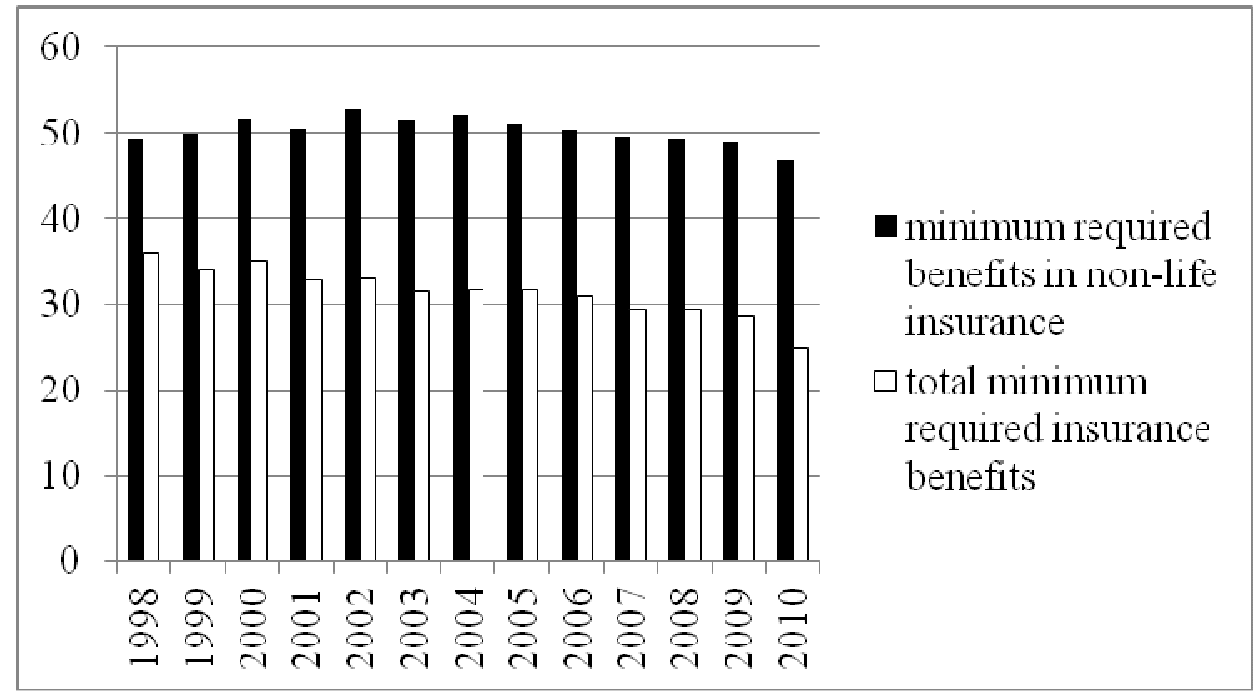

Source: Data from Annual reports (Czech Insurance Association, 2000-2010) acquired and assimilated by the author. 
Simultaneously, the market structure is changing. Some insurance companies with a traditionally higher market share have lost their share while the market share of other insurance companies is growing. In the past two years, insurance companies have been reacting to this shift by lowering prices of auto insurance products and by changing its policy, for example, by introducing a new type of insurance such as fleet insurance which applies to a whole group of automobiles with a lower coverage. Insurance companies then use such mandatory liability insurance at lower rates (which may, in fact, turn out to be unprofitable) as the basis for offering other insurance products.

\section{Fig. 3: Premium written in Auto Insurance in the Czech Republic} (in mil. CZK)

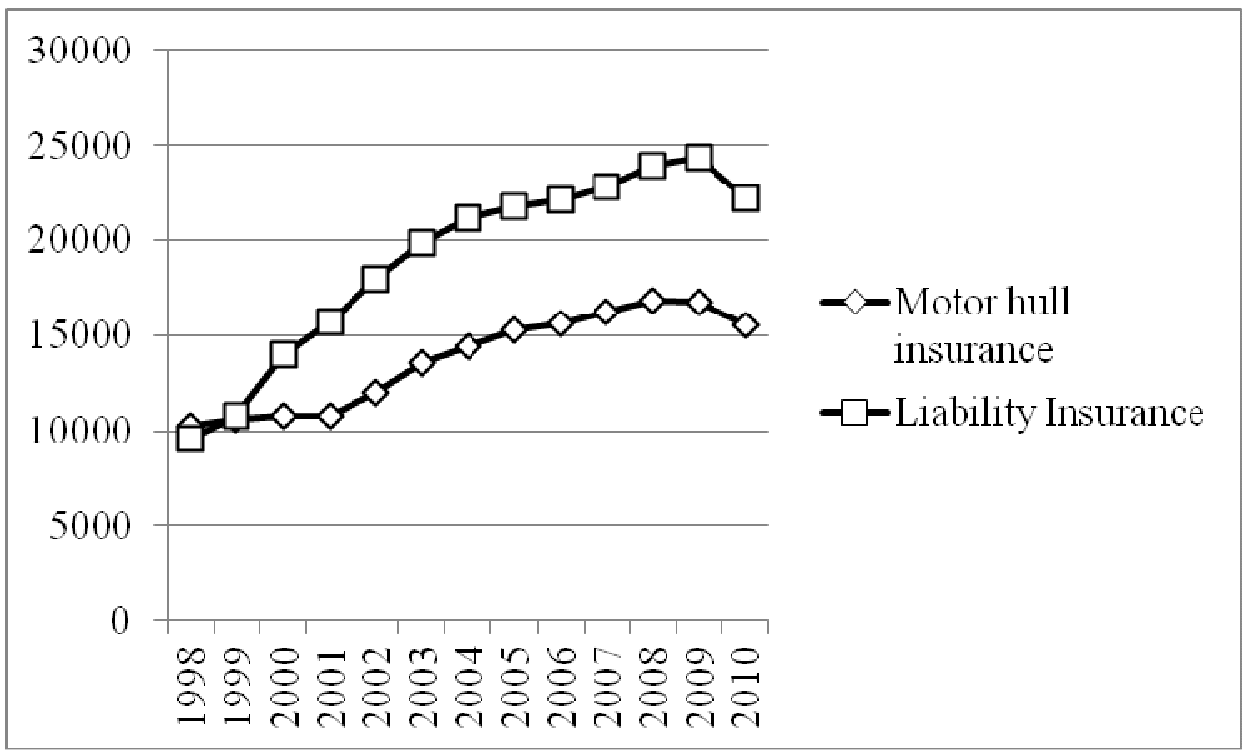

Source: Data from Annual reports Czech Insurance Association (2000-2010) and statistical Czech Insurance Association (2011) data acquired and assimilated by the author.

\section{Changes in Auto Insurance Policy}

Liability insurance policy is considerably dependent on the regulation of the form of the insurance product (Daňhel, 2006, p. 165). On one hand, this regulation specifies insurance coverage events; on the other hand, it specifies the extent of covered damage. Historically, both cases point to an extension of insurance protection. i.e. to other entities entitled to 
insurance payments and to an increase in payment limits. At the same time, there has been a trend towards a deregulation of price setting, particularly in the Czech Republic. Strict regulation connected to a legal form of coverage has been eased, and the approach to price setting currently employs various forms of segmentation as in the case of collision insurance. Various differentiating criteria result from the characteristics of the used vehicle (cylinder volume, age, make, etc.) and from the characteristics of the involved individuals (driver's experience, sex, age, etc.). The price of collision insurance is also heavily affected by other elements of the insurance policy such as various forms of a deductible. Likewise, a significant role in insurance price setting is also attributed to a follow-up insurance differentiation (Vostatek, 1996, p. 444).

There is also a tendency to extend the range of covered events such as baggage insurance, windshield and other glass insurance, additional accessories coverage, temporary car rental coverage, road assistance insurance, and legal protection insurance. There is an obvious development in collision insurance towards the so called "brick box" system which enables clients to adjust the structure of covered risks of damage according to a demand. A novelty in collision insurance policy, particularly in relation to insurance of entrepreneurs, is so called „fleet insurance", which covers a whole group of vehicles under one insurance contract.

Liability insurance policies also noticed some changes. In the Czech market, this development resulted in stricter penalties for vehicle owners who do not meet the mandatory insurance requirement. Therefore, a new contribution to a warranty fund for uninsured vehicles has been introduced which has led to a reduction in the amount of uninsured and registered vehicles. Also, an increase in insurance payment limits is expected in terms of other regulatory measures.

In addition, the issue of financing rescue system activities under liability insurance is under discussion. A $4 \%$ insurance transfer of a given insurance policy to the Ministry of Interior is also proposed to cover firemen and other rescue operations assisting in traffic accidents.

Individual insurers are responding to the tougher competition and to the reductions in mandatory liability insurance coverage in the Czech market by innovations in their product policies. In addition to the standard 
segmentation criteria (such as engine volume, deductible rate, car efficiency, "bonus-malus" system), other criteria such as the actual insured individual, their age, and place of residence are increasingly used as criteria for price setting. Due to latest technical developments, engine volume may be replaced by the criterion of engine power. The "bonusmalus" system is also in process of being adjusted to a more objective standard.

Insurance protection via supplementary services is making liability insurance coverage more attractive. These services include various levels of road assistance as part of mandatory liability insurance, legal assistance, technical assistance (car repair and towing service, temporary car, fuel, etc.). Liability insurance may now also cover damage to automobile as a result of a natural disaster or an animal encounter. Moreover, mandatory insurance may also include bodily injury insurance when a pre-defined part of the coverage is applied to cases of permanent damage to health, disability benefit payments, and child injury insurance. The latest includes coverage of damage to a vehicle which has been caused indirectly. Fine insurance is another such novelty. Moreover, insurance companies now offer alternative sales methods and contract sign-ups over the phone or the internet.

\section{Principle Innovations in Auto Insurance}

\section{GAP Insurance}

The insurance market also responds to problematic issues such as the extent of standard insurance coverage, in particular collision insurance. GAP (Guaranteed Asset Protection Insurance) is one of the examples. Simply put, this insurance covers the difference between the compensation of a damage covered by collision insurance and the purchase price of a new automobile.

This type of insurance was adopted by the Czech market from abroad where it is often offered as part of leasing contracts. To illustrate this, the price of a new vehicle starts to decrease rapidly after purchase. In a year, the general automobile value drops by about one third; in three years, it drops down to about a half of the original price. The difference between the car market value and its original purchase price may, therefore, be covered by GAP (See Fig. 4). 
Fig. 4: Schema of the development of insurance benefit payments

\section{in relation to GAP}

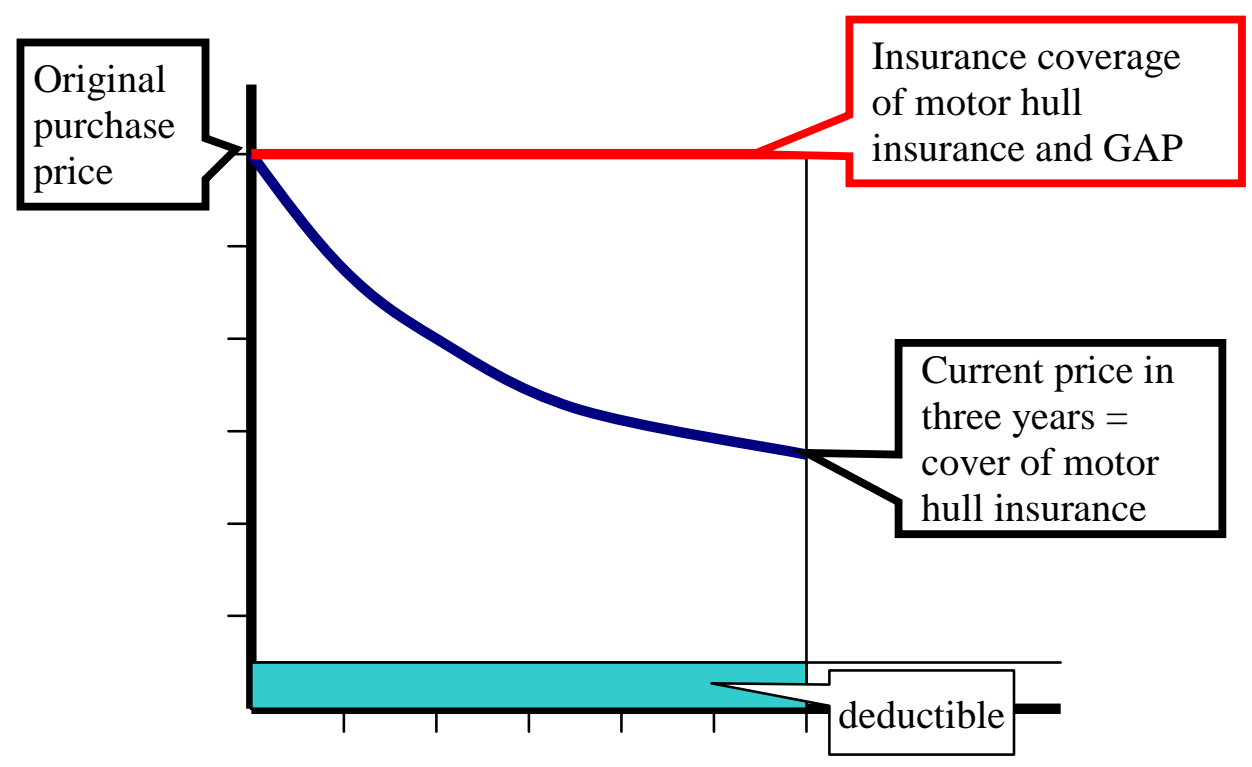

\section{Pay-As-You-Drive Insurance}

To ensure a higher degree of objectivity in automobile insurance, a new insurance product called Pay-As-You-Drive, is coming to the forefront worldwide. This type of insurance has become a popular alternative to liability insurance in many places such as California, South Africa, Australia, and Israel. The main difference is a variable insurance rate which is calculated based on the amount of actual kilometres the individual has driven; every kilometre is estimated based on driving during the day, at night, or in rush hour. The goal is to motivate the driver to drive the least amount of kilometres. Drivers may then choose alternative means of transportation during rush hour which may alleviate traffic jams during this time of the day. People are thus able to easily check their automobile insurance costs. This insurance policy may also lead to a decrease in the number of uninsured drivers who use their automobiles to a limited extent, and, as a result, have low motivation to take out collision insurance. 
The insurance policy is designed on the basis of kilometres driven by the client, which is a key factor for the insurance company. Therefore, the client has to purchase or rent identification equipment such as an odometer or a GPS style gauge, which enables the insurance company to collect needed data. Since insurance is calculated based on the number of driven kilometres, drivers with a high-volume driving would pay significantly more via the Pay-As-You-Drive system than if they had a standard insurance rate. Therefore, Pay-As-You-Drive insurance is recommended to:

- drivers who drive less than an average driver, i.e. occasional drivers who drive less than $10,000 \mathrm{~km}$ per year,

- people who use public transportation,

- people who live close to work,

- young inexperienced drivers who are often sanctioned by insurance companies for their lack of driving experience and who, consequently, pay higher insurance.

\section{Other Forms of Auto Insurance}

Other new forms of auto insurance include deductible insurance, extended vehicle warranty insurance, fine insurance, and motorist protection insurance.

Motorist protection insurance has been recently introduced to the Czech market. It requires installation of a dashboard gauge which sends out information about the location of the vehicle when needed (in case of theft or collision); the data is then processed in the customer service center and assistance is dispatched.

Insurance companies also offer deductible insurance as a part of motor hull insurance. The amount of deductible as agreed on in the insurance contract is then applied to motor hull insurance benefit payments for the insured event.

Another innovative product is extended warranty insurance. Car manufacturers and dealers are legally bound to offering a two-year warranty. Some car manufacturers offer a three-year or even a seven-year warranty which is, however, limited to a set amount of driven kilometres. The client may also take out special insurance to cover damages during the extended warranty period. The covered risk then includes a vehicle 
defect which occurred after the standard warranty period and generally applies to engine, gearbox, drive system, fuelling and cooling system, electrical wiring, brakes and steering. The client is responsible for having the car serviced based on the regulations of the manufacturer; all car maintenance services and repairs must be recorded in the vehicle service book; the defects cannot be caused by collision or wear and tear.

Fine insurance is designed to alleviate the financial impact of administrative procedures and driver license suspension due to violation of traffic regulations, which is contrary to ethical insurance principles.

\section{Conclusion}

Auto insurance represents one of the major areas of insurance markets. Due to the significance of its coverage, auto liability insurance is strictly regulated, particularly in terms of contents and policy the basis of which is legally established according to the European Union. The Czech market has developed towards a greater variety of offered products, mainly in terms of price setting, range of supplementary services such as assistance services, coverage of damages (due to traffic accident cause by the other driver, natural disasters, fine coverage, and personal injury coverage).

Motor hull insurance which covers the negative impact of automobile owners is heading towards greater protection insurance (i.e. assistance services insurance, additional accessories insurance, etc.) and towards policies corresponding to the market demands. To provide greater coverage for property damage, new products such as the GAP are entering the market.

Due to the nature of risks covered under auto insurance policies, more variable forms of products which take into account the degree and the type of car usage (e.g. Pay-As-You-Drive) are introduced. As a result of their efforts to assert themselves on the market, insurance companies are likely to introduce new products with a specific focus which will respond directly to the client's financial losses and to the significance of automobile transportation.

Overall, price reduction and its possible impact (operation of mandatory insurance becomes unprofitable for insurers), policies of insurance companies, their response to tougher competition, and their interest in mandatory insurance, which they use as the basis for creating stronger 
relationships with clients, currently rank among the most prominent discussion issues.

\section{References}

[1] Bauer, T. - Melle, L. (2007): European Motor Markets. Zurich, Swiss Reinsurance Company, 2007.

[2] Czech Insurance Association (2000-2010): Annual Reports 1999-2009. [on-line], Praha, Czech Insurance Association, c2000-2010, [cit. $14^{\text {th }}$ October, 2011],

<http://www.cap.cz/ItemF.aspx?list=DOKUMENTY_01\&view=pro+ web+V\%c3\%bdro\%c4\%8dn\%c3\%ad+zpr\%c3\%a1vy+EN>.

[3] Czech Insurance Association (2011): Statistics. Insurance of Vehicles. [on-line], Praha, Czech Insurance Association, c2011, [cit. $14^{\text {th }}$ October, 2011], <http://www.cap.cz/ItemF.aspx?list=DOKUMENTY_02\&view=pro+ web+pravideln\%c3\%a9+\%c4\%8dtvrtletn\%c3\%ad+statistiky+EN>.

[4] Czech Insurers' Bureau (2001-2010): Annual Reports 2000-2009. [on-line], Praha, Czech Insurance Association, c2000-2010, [cit. $14^{\text {th }}$ October, 2011],

$<$ http://www.cap.cz/ItemF.aspx?list=DOKUMENTY_01\&view=pro+ web+V\%c3\%bdro\%c4\%8dn\%c3\%ad+zpr\%c3\%a1vy+EN>.

[5] Daňhel, J. aj. (2006): Pojistná teorie. (In English: Insurance Theory). Praha, Professional Publishing, 2006.

[6] Majtánová, A. - Daňhel, J. - Ducháčková, E. - Kafková, E. (2006): Pojištovnictví - Teorie a praxe. (In English: The Insurance Industry: Theory and Practice.) Praha, Ekopress 2006.

[7] Šitner, R. (2011): Ceny povinného ručení jsou u dna. (In English: Prices for Liability Coverage are at the Bottom.) Hospodářské noviny, $18^{\text {th }}$ March, 2011.

[8] Vostatek, J. (1996): Sociální a soukromé pojištění (In English: Social and Private Insurance.) Praha, CODEX Bohemia, 1996. 


\title{
Current Issues of Automobile Insurance
}

\author{
Eva DUCHÁČKOVÁ
}

\begin{abstract}
Auto insurance belongs to the most important areas of the insurance market from the quantitative point of view and based on its significance in covering auto-related risks. The significance of damage impact, particularly in liability insurance, requires a high degree of regulation. Standard products, auto liability and collision insurance are following the overall changes in insurance policies and are adjusting to the changing conditions. One of the major issues in the auto insurance in the Czech Republic and internationally is a toughening competition which results in changing insurance premiums. At the same time, new forms of auto insurance are introduced due to technological advances and demands for higher coverage.
\end{abstract}

Key words: Insurance market; Motor hull insurance; Liability insurance; GAP insurance; Pay-As-You-Drive Insurance

JEL classification: G22 